\title{
ANALISA DETERMINAN PERILAKU SEKS BEBAS DI SMA NEGERI 1 KOTA FAJAR DI KABUPATEN ACEH SELATAN
}

\author{
Mayang Wulan \\ Prodi D IV Kebidanan, Fakultas Farmasi dan Kesehatan, Institut Kesehatan Helvetia, Medan. 082276088733 \\ mayangwulan@helvetia.ac.id
}

\begin{abstract}
ABSTRAK
Perilaku seksual yang tidak sehat di kalangan remaja khususnya remaja yang belum menikah cenderung meningkat. World Health Organization (WHO) tahun 2017, tingkat aborsi lebih tinggi di daerah berkembang daripada di daerah maju. Hasil Survei Demografi Kesehatan Indonesia 2012, Komponen Kesehatan Reproduksi Remaja, menunjukkan bahwa sekitar 9,3\% atau sekitar 3,7 juta remaja menyatakan pernah melakukan hubungan seksual pranikah. Tujuan Penelitian ini untuk menganalisa determinan perilaku seks Bebas di SMA Negeri 1 Kota Fajar di Kabupaten Aceh Selatan. Desain penelitian adalah survei analitik dengan pendekatan cross sectional. Lokasi penelitian di SMA Negeri 1 Kota Fajar. Populasi adalah seluruh siswa SMA Negeri 1 Kota Fajar dari kelas X sampai dengan XI sebanyak 484 orang dan pengambilan sampel dengan cara stratified random sampling sebanyak 83 orang. Analisa data menggunakan analisis univariat, bivariat dengan uji statistic chi-square dan multivariat dengan uji binary logistic. Hasil penelitian dengan uji chi-square menunjukkan ada hubungan pengetahuan $(0,000)$, sikap $(0,027)$, teman sebaya $(0,012)$, media sosial $(0,022)$ dan peran orang tua $(0,014)$, sedangkan uji regresi logistik menunjukkan media sosial $(19,121)$ adalah yang faktor paling dominan berpengaruh terhadap perilaku seks bebas pada remaja SMA Negeri 1 Kota Fajar di Kabupaten Aceh Selatan.
\end{abstract}

Kata kunci : determinan; perilaku seks bebas; remaja

\section{DETERMINANT ANALYSIS OF FREE SEX BEHAVIOR AT SMA NEGERI 1 FAJAR CITY OF SOUTH ACEH DISTRICT}

\begin{abstract}
Unhealthy sexual behavior among teenagers, especially unmarried adolescents, tends to be increased. World Health Organization (WHO); in 2017, abortion rates are higher in developing regions than in developed areas. Indonesian Demographic Health Survey, Adolescent Reproductive Health Components in 2012 showed around 9.3\% or about 3.7 million adolescents stated that they had had premarital sexual relations. The purpose of this study was to analyze the determinants of free sex in SMA Negeri 1 Kota Fajar in South Aceh Regency. The study design was an analytic survey with a cross-sectional approach. The population is all students of SMA Negeri 1 Kota Fajar from class X to XI as many as 484 people and sampling used stratified random sampling of 83 people. Data analysis used univariate analysis, bivariate with chi-square statistical test, and multivariate with the binary logistic test. The results of the study with the chi-square test showed there was a relationship of knowledge $(0,000)$, attitude $(0.027)$, peers $(0.012)$, social media $(0.022)$, and the role of parents $(0.014)$. In contrast, the logistic regression test showed social media (19.121) was the most dominant factor influencing free sex behavior in adolescents of SMA Negeri 1 Kota Fajar in South Aceh Regency.
\end{abstract}

Keywords: determinant; free sex behavior; teenagers. 


\section{LATAR BELAKANG}

Perilaku seksual yang tidak sehat di kalangan remaja khususnya remaja yang belum menikah cenderung meningkat. Hubungan seksual sebelum nikah pada remaja merupakan masalah yang serius, berhubungan dengan peningkatan penularan penyakit menular seksual, mempunyai pasangan lebih dari satu, dan kehamilan dini. Banyaknya remaja yang telah melakukan hubungan seksual sebelum menikah menjadi pemikiran serius bagi orang tua, masyarakat, pendidik, agamawan bahkan remaja itu sendiri (Yusuf. S, 2013)..

World Health Organization (WHO) tahun 2017, Tingkat aborsi lebih tinggi di daerah berkembang daripada di daerah maju. Sekitar 25 juta aborsi yang tidak aman diperkirakan terjadi di seluruh dunia setiap tahun, hampir di negara-negara berkembang. Setiap tahun antara 4,7\% - 13,2\% kematian maternal dapat dikaitkan dengan aborsi yang tidak aman. Sekitar 7 juta wanita dirawat di rumah sakit akibat aborsi yang tidak aman setiap tahun di negara-negara berkembang (WHO, 2017).

Hasil Survei Demografi Kesehatan Indonesia 2012 komponen Kesehatan Reproduksi Remaja (SDKI 2012 KRR), bahwa secara nasional terjadi peningkatan angka remaja yang pernah melakukan hubungan seksual pranikah dibandingkan dengan data hasil Survei Kesehatan Reproduksi Remaja Indonesia (SKRRI) 2007. Hasil survei SDKI 2012 menunjukkan bahwa sekitar 9,3\% atau sekitar 3,7 juta remaja menyatakan pernah melakukan hubungan seksual pranikah, sedangkan hasil SKRRI 2007 hanya sekitar 7\% atau sekitar 3 juta remaja. Sehingga selama periode tahun 2007 sampai 2012 terjadi peningkatan kasus remaja yang pernah melakukan hubungan seksual pranikah sebanyak 2,3\% (SDKI, 2012).

Dinas Kesehatan Aceh (Dinkes Aceh) 2016 menyebutkan remaja baik laki-laki maupun perempuan yang mengaku pernah berhubungan seks setahun terakhir dan berhubungan seks dengan lebih dari satu pasangan ada $43 \%$. Selama 4 tahun terakhir di Aceh telah ditemukan 22 orang penderita HIVIAIDS positif yang tersebar dibeberapa Kabupaten di Aceh. Penyakit tersebut mulai ditemukan pada tahun 2004 dengan jumlah satu kasus HIVIAIDS positif, pada tahun 2007 menjadi 22 kasus. Pria menjadi penderita terbanyak, sebesar 12 orang (63\%) sisanya adalah perempuan (Dinas Kesehatan Provinsi NAD, 2008).

Hasil penelitian Mahmudah dengan judul Faktor-faktor yang berhubungan dengan perilaku seksual remaja di Kota Padang. Jenis penelitian ini adalah analitik dengan desain cross sectional. Hasil analisis menunjukkan responden yang berperilaku seksual berisiko $(20,9 \%)$, jenis kelamin laki-laki (38,6\%), pubertas di usia <11 tahun (6,3\%), tingkat pengetahuan kurang $(1,9 \%)$, mendapat paparan tinggi dengan sumber informasi seksual $(19,6 \%)$ dan yang memiliki sikap negatif $(34,8 \%)$. Variabel yang memiliki nilai $p<0,05$ adalah jenis kelamin, paparan dengan sumber informasi seksual dan sikap terhadap berbagai perilaku seksual (Mahmudah, 2015).

Masa remaja merupakan masa yang sangat penting dan krisis sehingga memerlukan dukungan pengarahan yang positif baik dari keluarga maupun sekolah. Periode remaja merupakan klimaks dari metode-metode sebelumnya, sehingga dalam periode selanjutnya individu telah mempunyai suatu pola pribadi yang lebih mantap (Yusuf. S, 2013).

Kenakalan remaja bukan karena murni dari dalam diri remaja itu sendiri, tetapi mungkin kenakalan itu merupakan efek samping dari hal-hal yang tidak dapat ditanggulangi oleh remaja dalam keluarga (Agoes dariyo, 2012). Perilaku seksual beresiko tinggi menempatkan remaja pada resiko untuk infeksi menular seksual (IMS) termasuk juga Human Immunodeficiency Virus (HIV), dan kehamilan yang tidak direncanakan (Puspita et al., 2017).

Selain itu remaja lebih banyak berada di luar rumah bersama dengan teman-teman sebaya sebagai kelompok, maka dapatlah dimengerti bahwa pengaruh teman-teman sebaya pada sikap, pembicaraan, minat, penampilan, dan perilaku lebih besar daripada pengaruh keluarga. (Hurlock, 2010)

Berdasarkan survei awal, hasil wawancara dengan 15 orang siswa di SMA Negeri 1 Kota Fajar, 7 orang memiliki pengetahuan baik serta 
sikap yang positif tentang seks bebas dan mengatakan pernah melakukan perilaku seksual dengan lawan jenis seperti berciuman dan berpegangan tangan yang disebabkan oleh media sosial dan informasi dari teman sebaya, orang tua mereka membebaskan mereka untuk bergaul dengan siapa saja, sedangkan 8 orang lainnya memiliki pengetahuan kurang baik dan dari 8 orang tersebut 5 orang memiliki sikap yang positif dan 3 orang yang memiliki sikap negatif, 4 orang diantaranya tidak terlalu dekat dengan orang tua dan dibebaskan dalam bergaul dengan teman-temannya, sedangkan 4 orang diantaranya tinggal dengan orang tua tetapi mereka mengaku mempunyai teman-teman yang semuanya berpacaran dan sering menonton video porno. Hasil wawancara dengan salah satu guru di SMA Negeri 1 Kota Fajar memberikan keterangan bahwa hingga periode tahun 2016-2019 kasus perilaku seksual remaja seperti berciuman, berpegangan tangan terus terjadi dan tiap tahun tersebut ada siswa yang dipanggil orang tuanya untuk diberikan sanksi.

Hasil wawancara dengan salah satu siswa juga didapatkan informasi di tahun 2017-2018 masing-masing ada 1 orang siswa yang mengundurkan diri dari sekolah karena hamil di luar nikah dan tidak bisa melanjutkan pendidikannya. Tujuan Penelitian ini untuk menganalisa determinan perilaku seks Bebas di SMA Negeri 1 Kota Fajar di Kabupaten Aceh Selatan. Berdasarkan uraian diatas penulis tertarik melakukan penelitian berjudul "Analisa Determinan Perilaku Seks Bebas pada Remaja di SMA Negeri 1 Kota Fajar di Kabupaten Aceh Selatan".

\section{METODE}

Jenis penelitian ini adalah penelitian survei analitik (survei atau penelitian yang mencoba menggali bagaimana dan mengapa fenomena kesehatan itu terjadi) menggunakan pendekatan cross sectional yang bertujuan untuk melakukan pengukuran atau pengamatan pada saat bersamaan (sekali waktu) risiko atau paparan dengan penyakit (Notoatmodjo, 2010). Penelitian ini dilakukan di SMA Negeri 1 Kota Fajar Aceh Selatan yang dilaksanakan pada bulan April 2019. Populasi adalah seluruh siswa SMA Negeri 1 Kota Fajar dari kelas $X$ sampai dengan XI sebanyak 484 orang dan pengambilan sampel dengan cara stratified random sampling sebanyak 83 orang. Instrumen pengumpulan data mengunakan kuesioner. Uji statistic yang digunakan adalah uji statistic chi-square, dan uji multivariat menggunakan uji binary logistic.

\section{HASIL}

Analisis bivarat digunakan untuk menganilisa data dengan tujuan untuk menggetahui hubungan pengetahuan, sikap, teman sebaya, media sosial, peran orang tua dengan perilaku seks bebas pada remaja (tabel 1 ).

Tabel 1 menunjukkan bahwa dari 83 responden $(100 \%)$ terdapat 30 responden $(36,1 \%)$ pengetahuan baik dengan perilaku seks beresiko sebanyak 3 responden (3,6\%), dan perilaku seks tidak beresiko sebanyak 27 responden (32,5\%), dari 32 responden $(38,6 \%)$ pengetahuan cukup dengan perilaku seks beresiko sebanyak 6 responden $(7,2 \%)$, dan perilaku seks tidak beresiko sebanyak 26 responden $(31,3 \%)$ dan dari 21 responden (25,3\%) pengetahuan kurang dengan perilaku seks beresiko sebanyak 12 responden (14,5\%), dan perilaku seks tidak beresiko sebanyak 9 responden $(10,8 \%)$. Hasil uji statistik dengan menggunakan uji chi square, diperoleh hasil perhitungan $p$ value $=0,000<\alpha=0,05$, dapat disimpulkan ada hubungan pengetahuan dengan perilaku seks bebas pada remaja SMA Negeri 1 Kota Fajar Di Kabupaten Aceh Selatan Tahun 2019.

Tabel 1 menunjukkan bahwa dari 83 responden (100\%) terdapat 43 responden $(51,8 \%)$ sikap positif dengan perilaku seks beresiko sebanyak 6 responden $(7,2 \%)$, dan perilaku seks tidak beresiko sebanyak 37 responden (44,6\%), dari 40 responden $(48,2 \%)$ sikap negatif dengan perilaku seks beresiko sebanyak 15 responden (18,1\%), dan perilaku seks tidak beresiko sebanyak 25 responden (30,1\%). Hasil uji statistik dengan menggunakan uji chi square, diperoleh hasil perhitungan $p$ value $=0,027<\alpha=0,05$, dapat 
disimpulkan ada hubungan sikap dengan perilaku seks bebas pada remaja SMA Negeri 1 Kota Fajar Di Kabupaten Aceh Selatan Tahun 2019.

Variabel teman sebaya menunjukkan bahwa dari 83 responden (100\%) terdapat 56 responden $(67,5 \%)$ pengaruh teman sebaya kurang dengan perilaku seks beresiko sebanyak 9 responden $(10,8 \%)$, dan perilaku seks tidak beresiko sebanyak 47 responden (56,6\%), dari 27 responden (32,5\%) pengaruh teman sebaya baik dengan perilaku seks beresiko sebanyak 12 responden (14,5\%), dan perilaku seks tidak beresiko sebanyak 15 responden $(18,1 \%)$. Hasil uji statistik dengan menggunakan uji chi square, diperoleh hasil perhitungan $p$ value $=0,012<\alpha=0,05$, dapat disimpulkan ada hubungan teman sebaya dengan perilaku seks bebas pada remaja SMA Negeri 1 Kota Fajar Di Kabupaten Aceh Selatan Tahun 2019.

Variabel media sosial menunjukkan bahwa dari 83 responden (100\%) terdapat 58 responden $(69,9 \%)$ media sosial baik dengan perilaku seks beresiko sebanyak 10 responden (12\%), dan perilaku seks tidak beresiko sebanyak 48 responden (57,8\%), dari 25 responden $(30,1 \%)$ media sosial kurang dengan perilaku seks beresiko sebanyak 11 responden $(13,3 \%)$, dan perilaku seks tidak beresiko sebanyak 14 responden (16,9\%). Hasil uji statistik dengan menggunakan uji chi square, diperoleh hasil perhitungan $p$ value $=$ $0,022<\alpha=0,05$, dapat disimpulkan ada hubungan media sosial dengan perilaku seks bebas pada remaja SMA Negeri 1 Kota Fajar di Kabupaten Aceh Selatan.

Variabel perang orangtua menunjukkan bahwa dari 83 responden (100\%) terdapat 37 responden $(44,6 \%)$ peran orang tua baik dengan perilaku seks beresiko sebanyak 4 responden $(4,8 \%)$, dan perilaku seks tidak beresiko sebanyak 33 responden $(39,8 \%)$, dari 46 responden $(55,4 \%)$ peran orang tua kurang dengan perilaku seks beresiko sebanyak 17 responden (20,5\%), dan perilaku seks tidak beresiko sebanyak 29 responden (34,4\%). Hasil uji statistik dengan menggunakan uji chi square, diperoleh hasil $p$ value $0,014<\alpha 0,05$, dapat disimpulkan ada hubungan peran orang tua dengan perilaku seks bebas pada remaja SMA Negeri 1 Kota Fajar Di Kabupaten Aceh Selatan.

Tabel 1. Hubungan Pengetahuan, Sikap, Teman Sebaya, Media Sosial, Peran Orang Tua dengan Perilaku Seks Bebas Pada Remaja $(n=83)$

\begin{tabular}{|c|c|c|c|c|c|c|c|}
\hline \multirow{3}{*}{$\begin{array}{l}\text { Variabel/ } \\
\text { Kategori }\end{array}$} & \multicolumn{4}{|c|}{ Perilaku Seks Bebas } & & & \multirow{3}{*}{ P-Value } \\
\hline & \multicolumn{2}{|c|}{ Beresiko } & \multicolumn{2}{|c|}{$\begin{array}{c}\text { Tidak } \\
\text { Beresiko }\end{array}$} & \multicolumn{2}{|c|}{ Total } & \\
\hline & $f$ & $\%$ & $f$ & $\%$ & $f$ & $\%$ & \\
\hline \multicolumn{8}{|l|}{ Pengetahuan } \\
\hline Baik & 3 & 3,6 & 27 & 32,5 & 30 & 36,1 & \multirow{3}{*}{0,000} \\
\hline Cukup & 6 & 7,2 & 26 & 31,3 & 32 & 38,6 & \\
\hline Kurang & 12 & 14,5 & 9 & 10,8 & 21 & 25,3 & \\
\hline \multicolumn{8}{|l|}{ Sikap } \\
\hline Positif & 6 & 7,2 & 37 & 44,6 & 43 & 51,8 & \multirow{2}{*}{0,027} \\
\hline Negatif & 15 & 18,1 & 25 & 30,1 & 40 & 48,2 & \\
\hline \multicolumn{8}{|l|}{ Teman Sebaya } \\
\hline Baik & 9 & 10,8 & 47 & 56,5 & 56 & 67,5 & \multirow{2}{*}{0,012} \\
\hline Kurang & 12 & 14,5 & 15 & 18,1 & 27 & 32,5 & \\
\hline \multicolumn{8}{|l|}{ Media Sosial } \\
\hline Baik & 10 & 12 & 48 & 57,8 & 58 & 69,9 & \multirow{2}{*}{0,022} \\
\hline Kurang & 11 & 13,1 & 14 & 16,9 & 25 & 30,1 & \\
\hline \multicolumn{8}{|c|}{ Peran Orang Tua } \\
\hline Baik & 4 & 4,8 & 33 & 39,8 & 37 & 44,6 & \multirow{2}{*}{0,014} \\
\hline Kurang & 17 & 20,5 & 29 & 34,4 & 46 & 55,4 & \\
\hline
\end{tabular}


Tahapan setelah dilakukan analisis bivarat adalah analisis multivariat yang bertujuan untuk mengetahui faktor paling dominan yang mempengaruhi perilaku seks bebas pada remaja (tabel 2).

\section{Tabel 2. Hasil Variabel in the Equation}

\begin{tabular}{lrrrrrr}
\hline \multicolumn{1}{c}{ Variabel } & B & S.E & Wald & Df & Sig & Exp. (B) \\
\hline Pengetahuan & 1.603 & .537 & 8.925 & 1 & .003 & 4,969 \\
Sikap & 1.565 & .764 & 4.200 & 1 & .040 & 4,782 \\
Teman Sebaya & 2.388 & .866 & 7.608 & 1 & .006 & 10,896 \\
Media Sosial & 2.951 & .988 & 8.914 & 1 & .003 & 19.121 \\
Peran Orang tua & 1.890 & .825 & 5.251 & 1 & .022 & 6.617 \\
Constant & -15.447 & 4.166 & 13.748 & 1 & .000 & .000 \\
\hline
\end{tabular}

Tabel 2 menunjukkan bahwa besarnya pengaruh ditunjukkan dengan nilai EXP (B) atau disebut juga Odds Ratio (OR). Variabel pengetahuan dengan OR 4,969 maka peluang perilaku seks bebas pada pengetahuan kurang yaitu 4,969 kali lebih beresiko dibandingkan dengan pengetahuan baik dan cukup. Nilai $B=$ Logaritma natural dari $4,969=1,603$. Oleh karena nilai $B$ bernilai positif, maka pengetahuan mempunyai pengaruh dengan perilaku seks bebas.

Variabel sikap dengan OR 4,782 maka peluang perilaku seks bebas pada sikap negatif yaitu 4,782 kali lebih beresiko dibandingkan dengan sikap positif. Nilai $B=$ Logaritma natural dari $4,782=1,565$. Oleh karena nilai $B$ bernilai positif, maka sikap mempunyai pengaruh dengan perilaku seks bebas.

Variabel teman sebaya dengan OR 10,896 maka peluang perilaku seks bebas pada teman sebaya kurang yaitu 10,896 kali lebih beresiko dibandingkan dengan teman sebaya baik. Nilai $B=$ Logaritma natural dari $10,896=2,388$. Oleh karena nilai $B$ bernilai positif maka teman maka peluang perilaku seks bebas pada peran orang tua kurang yaitu 6,617 kali lebih beresiko dibandingkan dengan peran orang tua baik. Nilai $B=$ Logaritma natural dari 6,617 $=1,890$. Oleh karena nilai $B$ bernilai positif, maka peran orang tua mempunyai pengaruh dengan perilaku seks bebas. Dari hasil analisis multivariat di atas diketahui bahwa media sosial adalah variabel yang paling dominan berpengaruh terhadap perilaku seks bebas yang dapat dilihat dari koefisien (B) yaitu 2,951 dengan nilai OR 19,121.

\section{PEMBAHASAN \\ Hubungan Pengetahuan Dengan Perilaku Seks Bebas Pada Remaja}

Hasil penelitian menunjukkan ada hubungan pengetahuan dengan perilaku seks bebas pada remaja SMA Negeri 1 Kota Fajar Di Kabupaten Aceh Selatan. Hasil penelitian ini sejalan dengan penelitian Darmasih dengan judul Faktor Yang Mempengaruhi Perilaku Seks Pranikah Pada Remaja Sma Di Surakarta. Analisis statistik yang digunakan dalam penelitian ini adalah statistik chi square (X2) dan regresi ganda (multiple regression), dengan tingkat kepercayaan $\alpha=0,05$. Berdasarkan hasil penelitian ini dapat diketahui bahwa ada pengaruh pengetahuan, pemahaman tingkat agama, sumber informasi, dan peranan keluarga terhadap perilaku seks pranikah pada remaja SMA di Surakarta (Darmasih, 2009).

Pengetahuan remaja tentang seks masih sangat kurang juga disebabkan karena faktor informasi keliru yang diperoleh dari sumber yang salah, seperti mitos seputar seks, VCD porno, situs porno di internet dan lainnya yang akan membuat pemahaman dan persepsi anak tentang seks menjadi salah (Yusuf S, 2012). Pengetahuan remaja yang kurang mengetahui tentang perilaku seks pra nikah, maka sangatlah mungkin jika membuat mereka salah dalam bersikap dan kemudian mempunyai perilaku terhadap seksualitas. (Soetjiningsih, 2010)

Penelitian ini juga sesuai hasilpenelitian Mariani dengan judul faktor-faktor yang mempengaruhi perilaku seksual remaja di SMP Negeri 15 Kota Cirebon. Analisis statistik 
menggunakan uji chi-square. Uji korelasi antara pengetahuan tentang kesehatan reproduksi dan perilaku seksual menunjukkan hubungan yang bermakna $(0,000)$. Begitupun dengan variabel lain seperti media informasi $(0,000)$ dan self-esteem $(=0,000)$ (Mariani \& Arsy, 2017).

Masa remaja adalah masa yang penuh gejolak, seorang remaja mengalami masa peralihan dari masa anak-anak ke masa dewasa. Pada masa ini, remaja yang mampu melewati masa sebelumnya dengan baik, akan dapat menerima kodratnya, baik sebagai pria maupun wanita. Pada remaja putri, masa ini berlangsung lebih singkat daripada remaja pria, sehingga proses kedewasaan remaja putri lebih cepat dicapai dibandingkan remaja pria (Utami, 2015).

Pengetahuan seksual yang baik dapat menjadikan remaja memiliki tingkah laku seksual yang sehat dan bertanggung jawab. Pemahaman yang keliru mengenai seksualitas pada remaja menjadikan mereka mencoba untuk bereksperimen mengenai masalah seks tanpa menyadari bahaya yang timbul dari perbuatannya, dan ketika permasalahan yang ditimbulkan oleh perilaku seksnya mulai bermunculan, remaja takut untuk mengutarakan permasalahan tersebut kepada orang tua (Mariani \& Arsy, 2017)

Asumsi peneliti, ada pengaruh pengetahuan dengan perilaku seks bebas pada remaja. Pengetahuan merupakan hal yang sangat penting dalam membentuk tindakan seseorang, dimana bahwa perilaku yang didasari oleh pengetahuan akan lebih baik daripada perilaku yang tidak didasari pengetahuan. Namun tidak semua orang yang berpengetahuan baik berperilaku baik. Diharapkan dengan pengetahuan yang baik, remaja dapat lebih menjaga kesehatan reproduksi dan menyalurkan secara tepat hasrat seksualnya pada kegiatan - kegiatan yang positif. Remaja yang berpengetahuan baik lebih cenderung menyalurkan hasrat seksualnya melalui cara yang tepat, karena mereka mengetahui dengan baik dampak akan timbul akibat perilaku seksual tersebut jika mereka melakukan. Pengetahuan sangatlah penting karena pengetahuan menentukan tindakan yang akan diambil oleh seseorang. Semakin baik pengetahuan maka harusnya semakin baik pula perilaku seseorang tersebut.

\section{Hubungan Sikap Dengan Perilaku Seks Bebas Pada Remaja}

Hasil penelitian menunjukkan ada hubungan sikap dengan perilaku seks bebas pada remaja SMA Negeri 1 Kota Fajar Di Kabupaten Aceh Selatan. Hasil penelitian ini sejalan dengan penelitian Mahmudah dengan judul Faktorfaktor yang berhubungan dengan perilaku seksual remaja di Kota Padang. Analisis data dilakukan dengan uji chi-square dengan tingkat kemaknaan 95\%. Hasil analisis menunjukkan ada hubungan jenis kelamin, paparan dengan sumber informasi seksual dan sikap terhadap berbagai perilaku seksual (Mahmudah, 2015).

Ketidaktahuan orangtua maupun sikap yang masih menabukan pembicaraan seks dengan anak, bahkan cenderung membuat jarak dengan anak tentang masalah ini akibatnya pengetahuan remaja tentang seksualitas sangat kurang. Peran orang tua dalam pendidikan anak sangatlah penting, terutama pemberian pangetahuan tentang seksualitas (Sarwono, 2015).

Sikap (Attitude) merupakan reaksi atau respon yang masih tertutup dari seseorang terhadap suatu stimulus atau objek (Ayu \& Kurniawati, 2017). Sikap remaja tentang hubungan seksual pranikah adalah respon yang ditampilkan remaja dalam meperlihatkan stimulus yang ada terhadap hubungan seksual pranikah. Pembentukan sikap dipengaruhi oleh agama dan orang lain yang dianggap penting serta faktor emosi dari dalam diri individu (Ramadhani \& Miftahul, 2019).

Asumsi peneliti, ada pengaruh sikap dengan perilaku seks bebas pada remaja. Kesediaan dan perhatian remaja terhadap seksualitas menjadi hal sangat penting yang harus diperhatikan. Penerimaan seksualitas dalam kehidupan mengharuskan orang tua dan orangorang terdekat lebih memperhatikan perkembangan remaja yang dapat dilihat dari sikapnya dalam keseharian. Sikap positif terhadap seksual dapat disebabkan karena remaja tersebut memiliki persepsi dan pengetahuan yang baik mengenai seksual 
pada remaja sehingga mereka mempunyai sikap yang positif, namun sikap yang negatif dapat muncul oleh karena pengetahuan yang kurang tentang seksualitas sehingga semakin negatif sikap remaja akan semakin beresiko dalam berperilaku tidak baik.

\section{Hubungan Teman Sebaya Dengan Perilaku Seks Bebas Pada}

Hasil penelitian menunjukkan ada hubungan teman sebaya dengan perilaku seks bebas pada remaja SMA Negeri 1 Kota Fajar Di Kabupaten Aceh Selatan. Begitu juga dengan penelitian Gustiana yang berjudul Hubungan Teman Sebaya Dengan Perilaku Seksual Bebas Pada Remaja Di SMK Bina Patria 2014. Hasil dari uji hipotesis penelitian yang ditemukan hasil $R=0,143 \mathrm{R}$ Square $=0,020$ dengan tingkat signifikasi $=0,451>0,05$ yang mengandung artian bahwa hasil uji hipotesis dalam penelitian ini diterima. (Gustiana et al., 2014).

Teman sebaya adalah anak- anak atau remaja dengan tingkat usia atau tingkat kedewasaan yang sama. Salah satu fungsi teman sebaya adalah untuk memberikan berbagai informasi dan perbandingan tentang dunia di luar keluarga (Chotima, 2015).

Remaja berusaha menemukan konsep dirinya di dalam kelompok sebaya. Disini ia dinilai oleh teman sebayanya tanpa memperdulikan sanksi-sanksi dunia dewasa. Kelompok sebaya memberikan lingkungan, yaitu dunia tempat remaja dapat melakukan sosialisasi di mana nilai yang berlaku bukanlah nilai yang ditetapkan oleh orang dewasa, melainkan oleh teman seusianya. Inilah letak berbahayanya bagi perkembangan jiwa remaja, apabila nilai yang dikembangkan dalam kelompok sebaya ini cenderung tertutup, di mana setiap anggota tidak dapat terlepas dari kelompoknya dan harus mengikuti nilai yang dikembangkan oleh pimpinan kelompok. Sikap, pikiran, perilaku, dan gaya hidupnya merupakan perilaku dan gaya hidup kelompoknya (Safitri \& Safrudin, 2018).

Asumsi peneliti, ada pengaruh teman sebaya dengan perilaku seks bebas pada remaja. Teman sebaya merupakan orang terdekat dalam kehidupan remaja, setiap remaja pasti memiliki teman sebaya dalam kehidupannya. dalam kehidupannya remaja sangat membutuhkan teman untuk dapat mencurahkan semua isi hatinya, dan pada saat ini teman sebaya berperan penting. Dalam kehidupan sehari-hari topik seksualitas merupakan topik yang umum dibicarakan oleh remaja, dalam hal ini teman sebaya dapat memberikan pendapat, solusi dan saran bahkan tentang pengalaman seksualitas yang telah dilakukannya. Biasanya pendapat, solusi maupun saran dari teman mudah diterima remaja dari pada saran atau anjuran dari orang tua meskipun solusi tersebut belum diketahui kebenarannya terutama tentang seksual.

\section{Hubungan Peran Orang Tua Dengan Perilaku Seks Bebas Pada Remaja}

Hasil penelitian menunjukkan ada hubungan peran orang tua dengan perilaku seks bebas pada remaja SMA Negeri 1 Kota Fajar Di Kabupaten Aceh Selatan. Hasil penelitian ini sejalan dengan penelitian Darmasih dengan judul Faktor Yang Mempengaruhi Perilaku Seks Pranikah Pada Remaja Sma Di Surakarta. Analisis statistik yang digunakan dalam penelitian ini adalah statistik chi square (X2) dan regresi ganda (multiple regression), dengan tingkat kepercayaan $\alpha=0,05$. Berdasarkan hasil penelitian ini dapat diketahui bahwa ada pengaruh pengetahuan, pemahaman tingkat agama, sumber informasi, dan peranan keluarga terhadap perilaku seks pranikah pada remaja SMA di Surakarta (Darmasih, 2009).

Ketidaktahuan orangtua maupun sikap yang masih menabukan pembicaraan seks dengan anak, bahkan cenderung membuat jarak dengan anak tentang masalah ini akibatnya pengetahuan remaja tentang seksualitas sangat kurang. Peran orang tua dalam pendidikan anak sangatlah penting, terutama pemberian pangetahuan tentang seksualitas (Sarwono, 2015).

Keluarga merupakan lingkungan pertama dan utama bagi perkembangan anak. Usia 4-5 tahun dianggap sebagai titik awal proses identifikasi diri menurut jenis kelamin, sehingga 
peran ibu dan ayah atau orang tua pengganti (nenek, kakek, dan orang dewasa lainnya) sangat besar. Apabila proses identifikasi ini tidak berjalan dengan lancar, maka dapat timbul proses identifikasi yang salah (Arikunto, 2015).

Bila setiap orang tua dan keluarga memberikan perhatian yang cukup pada remaja dan turut serta mendukung terpeliharanya nilai-nilai moral dan etika, maka akan tercipta suasana sehat bagi kehidupan remaja. Penanaman nilai-nilai budi pekerti dalam keluarga dapat dilakukan melalui keteladanan orang tua atau orang dewasa lainnya, bacaan yang sehat, pemberian tugas, dan komunikasi efektif antar anggota keluarga. Sebaliknya, apabila keluarga tidak peduli terhadap hal ini, misalnya membiarkan anak tanpa komunikasi dan memperoleh nilai di luar moral dan sosial, membaca buku dan menonton VCD porno, bergaul bebas, minuman keras dan merokok, maka akan berakibat buruk terhadap perkembangan jiwa remaja (Poltekkes Depkes Jakarta, 2014)

Faktor lingkungan yang berpengaruh terhadap perilaku reproduksi remaja di antaranya adalah faktor keluarga. Remaja yang melakukan hubungan seksual sebelum menikah banyak di antaranya berasal dari keluarga yang bercerai atau pernah cerai, keluarga dengan banyak konflik dan perpecahan. Peran orang tua remaja, mempunyai pengaruh langsung dan tidak langsung dengan perilaku seksual pranikah remaja. Faktor-faktor yang mempengaruhi perilaku seksual pranikah pada remaja paling tinggi adalah hubungan antara orang tua dengan remaja (Darmasih, 2009).

Asumsi peneliti, ada pengaruh peran orang tua dengan perilaku seks bebas pada remaja. Orang tua selayaknya memberikan perhatian pada remaja dalam kehidupan sehari-hari tanpa mengekang, meskipun diberikan kebebasan remaja tetap harus di kontrol. Bila perhatiaan yang diberikan baik maka anak akan berperilaku dengan baik dalam kehidupan sehari-hari, sedangkan bila orang tua tidak peduli dan memberikan perhatian kepada anak maka anak akan lebih mudah berpengaruh terhadap lingkungan sekitarnya sehingga anak dapat menerima perilaku yang kurang baik dari lingkungan dengan mudah. Komunikasi orang tua dan anak dapat menentukan seberapa besar kemungkinan anak melakukan tindakan seksual, semakin rendah komunikasi yang dilakukan maka akan semakin besar anak melakukan tindakan seksual.

\section{Hubungan Media Sosial Dengan Perilaku Seks Bebas Pada Remaja}

Hasil penelitian menunjukkan ada hubungan media sosial dengan perilaku seks bebas pada remaja SMA Negeri 1 Kota Fajar Di Kabupaten Aceh Selatan Tahun 2019. Hasil analisis multivariat dapat diketahui bahwa media sosial adalah variabel yang paling dominan berpengaruh terhadap perilaku seks bebas yang dapat dilihat dari persamaan regresi logistik yang menunjukkan nilai koefisien regresi (B) yaitu 2,951 dengan nilai OR 19,121.

Hasil penelitian ini sejalan dengan penelitian Mahmudah dengan judul Faktor-faktor yang berhubungan dengan perilaku seksual remaja di Kota Padang. Analisis data dilakukan dengan uji chi-square dengan tingkat kemaknaan 95\%. Hasil analisis menunjukkan ada hubungan jenis kelamin, paparan dengan sumber informasi seksual dan sikap terhadap berbagai perilaku seksual (Mahmudah, 2015).

Adanya penyebaran informasi dan rangsangan seksual melalui media massa yaitu dengan adanya teknologi yang canggih seperti VCD, Internet, majalah, TV, video. Remaja cenderung ingin tahu dan ingin mencoba-coba serta meniru dengan apa yang dilihat dan didengarnya, khususnya karena remaja pada umunya belum pernah mengetahui masalah seksual secara lengkap dari orang tuanya (Solikah et al., 2015).

Asumsi peneliti, ada pengaruh media sosial dengan perilaku seks bebas pada remaja. Dalam kehidupan sehari-hari media sosial memberikan peranan penting dalam menyampaikan berbagai konten atau informasi kepada banyak orang dan tidak terbatas pada satu orang tertentu, sehingga para pengguna media sosial dapat menerima informasi secara bebas tentang apapun secara online dalam waktu yang cepat. Penggunaan media sosial pada remeja semakin meningkat yang terlihat 
dari penggunaannya, setiap remaja memiliki handphone pribadi untuk dapat mengakses media sosial dengan mudah yang dapat dapat berdampak dalam kehidupan sehari-harinya, jika penggunaan media sosial dapat digunakan dengan baik maka informasi yang di dapat juga baik namun, jika penggunaan media sosial digunakan dengan tidak terkontrol maka informasi yang diperoleh juga tidak baik.

\section{Faktor yang mempengaruhi perilaku seks bebas pada remaja}

Besarnya pengaruh ditunjukkan dengan nilai EXP (B) atau disebut juga Odds Ratio (OR). Variabel pengetahuan dengan OR 4,969 maka peluang perilaku seks bebas pada pengetahuan kurang yaitu 4,969 kali lebih beresiko dibandingkan dengan pengetahuan baik dan cukup, variabel sikap dengan OR 4,782 maka peluang perilaku seks bebas pada sikap negatif yaitu 4,782 kali lebih beresiko dibandingkan dengan sikap positif, variabel teman sebaya dengan OR 10,896 maka peluang perilaku seks bebas pada teman sebaya kurang yaitu 10,896 kali lebih beresiko dibandingkan dengan teman sebaya baik, variabel peran orang tua dengan OR 6,617 maka peluang perilaku seks bebas pada peran orang tua kurang yaitu 6,617 kali lebih beresiko dibandingkan dengan peran orang tua baik, variabel media sosial dengan OR 19,121 maka peluang perilaku seks bebas pada media sosial kurang yaitu 19,121 kali lebih beresiko dibandingkan dengan media sosial baik.

Dari hasil uji binary logistic diketahui bahwa media sosial adalah variabel yang paling dominan berpengaruh terhadap perilaku seks bebas yang dapat dilihat dari persamaan regresi logistik yang menunjukkan nilai koefisien regresi (B) yaitu 2,951 dengan nilai OR 19,121.

Media sosial adalah media online yang mendukung interaksi sosial. Sosial media menggunakan teknologi berbasis web yang mengubah komunikasi menjadi dialog interaktif. Beberapa situs media sosial yang populer sekarang ini antara lain: Blog, Twitter, Facebook, Instagram, Path, dan Wikipedia. Penggunaan media sosial pada remeja semakin meningkat yang terlihat dari penggunaannya, setiap remaja memiliki handphone pribadi untuk dapat mengakses media sosial dengan mudah yang dapat dapat berdampak dalam kehidupan sehari-harinya, jika penggunaan media sosial dapat digunakan dengan baik maka informasi yang di dapat juga baik namun, jika penggunaan media sosial digunakan dengan tidak terkontrol maka informasi yang diperoleh juga tidak baik. Dalam kehidupan sehari-hari media sosial memegang peranan penting dalam memberikan berbagai informasi kepada semua orang.

\section{KESIMPULAN DAN SARAN}

Ada hubungan pengetahuan, sikap, teman sebaya, media sosial dan peran orang tua dengan perilaku seks bebas. Media sosial adalah faktor yang paling dominan berpengaruh terhadap perilaku seks bebas. Pihak sekolah diharapkan melibatkan orangtua saat memberikan penyuluhan tentang perilaku seks bebas, agar orangtua memahami dan ikut mengawasi penggunaan media sosial dalam kehidupan sehari-hari.

\section{REFERENSI}

Agoes Dariyo. (2012). Psikologi Perkembangan Remaja. Ghalia Indonesia.

Arikunto, S. (2015). Prosedur Penelitian (Suatu Pendekatan Praktek). Rineka Cipta.

Ayu, S. M., \& Kurniawati, T. (2017). Hubungan Tingkat Pengetahuan Remaja Putri Tentang Aborsi Dengan Sikap Remaja Terhadap Aborsi Di MAN 2 Kediri Jawa Timur. Unnes Journal Of Public Health, 6(2), 97-100.

Chotima, C. (2015). Pengaruh Pendidikan Keuangan Di Keluarga, Sosial Ekonomi Orang Tua, Pengetahuan Keuangan, Kecerdasan Spiritual, Dan Teman Sebaya Terhadap Manajemen Keuangan Pribadi Mahasiswa S1 Pendidikan Akuntansi Fakultas Ekonomi Universitas Negeri Surabaya. Jurnal Pendidikan Akuntansi (JPAK), 3(2).

Darmasih, R. (2009). Faktor Yang Mempengaruhi Perilaku Seks Pranikah Pada Remaja SMA Di Surakarta [DISS]. 
Universitas Muhammadiyah Surakarta.

Dinas Kesehatan Provinsi NAD. (2008). Laporan Survei Surveilans Perilaku Berisiko Tertular HIV Di Nanggroe Aceh Darussalam 2008.

Gustiana, D., Dewi, Y. I., \& Nurchayati, S. (2014). Faktor-Faktor Yang Berhubungan Dengan Perilaku Pencegahan Kanker Serviks Pada Wanita Usia Subur. Jurnal Online Mahasiswa Program Studi IImu Keperawatan Universitas Riau, 1(2), 1-8.

Hurlock, E. . (2010). Psikologi Perkembangan, Suatu Pendekatan Sepanjang Rentang Kehidupan. Erlangga.

Mahmudah. (2015). Faktor-Faktor Yang Berhubungan Dengan Perilaku Seksual Remaja Di Kotapadang [JOUR]. Unnes Journal Of Public Health, 4(3).

Mariani, N. N., \& Arsy, D. F. (2017). FaktorFaktor Yang Mempengaruhi Perilaku Seksual Remaja Di SMP Negeri 15 Kota Cirebon Tahun 2017 [JOUR]. Care: Jurnal IImiah IImu Kesehatan, 5(3), 443-456.

Notoatmodjo, S. (2010). Metodologi Penelitian Kesehatan. Jakarta: Rineka Cipta.

Poltekkes Depkes Jakarta. (2014). Kesehatan Remaja: Problem Dan Solusinya. Salemba Medika.

Puspita, I. M., Budiastuti, A., \& Pramono, D. (2017). Pengaruh Pendekatan Blended Learning Terhadap Pengetahuan Dan Sikap Siswa SMA Negeri 9 Semarang Tentang Infeksi Menular Seksual. Faculty Of Medicine.
Ramadhani, A., \& Miftahul, A. (2019). Pengaruh Sikap Rerhadap Perilaku Seksual Pra nikah pada Remaja di Kota Banyuwangi. Sosioedukasi: jurnal ilmiah ilmu pendidikan dan sosial, 8(1), 20-37.

Safitri, E. N., \& Safrudin, B. (2018). Hubungan Peer Group Dengan Perilaku Berpacaran Pada Remaja Kelas VII Dan VIII Di SMP Negeri 7 Samarinda.

Sarwono, S. W. (2015). Psikologi Remaja. Grafindo Persada.

SDKI. (2012). Pelatihan-Demografi.

Soetjiningsih. (2010). Tumbuh Kembang Remaja Dan Permasalahannya. Sagung Seto.

Solikah, I. A., Herlina, N., \& Masnina, R. (2015). Hubungan Antara Peran Media Sosial Dan Peran Orang Tua Dengan Perilaku Seks Pranikah Pada Remaja Kelas XII Di SMKN 4 Samarinda.

Utami, F. T. (2015). Penyesuaian Diri Remaja Putri Yang Menikah Muda. Psikis: Jurnal Psikologi Islami, 1(1), 11-21.

WHO. (2017). Media Centre News Releases 2017.

Yusuf. S. (2013). Psikologi Perkembangan Anak Dan Remaja. Rosda.

Yusuf S. (2012). Psikologi Perkembangan Anak Dan Remaja. Rosda. 